\title{
Neuropathic Pain in a Patient with Porphyria. Case Report
}

\author{
Alysson B. O. Santos ${ }^{1}$, Judymara L. Gozzani, TSA ${ }^{2}$, Daniela F. Groke ${ }^{3}$
}

\begin{abstract}
Summary: Santos ABO, Gozzani JL, Groke DF - Neuropathic Pain in a Patient with Porphyria. Case Report.
Background and objectives: Porphyrias represent a group of inherited or acquired disorders that involve enzymes that participate in heme synthesis. Acute manifestations affect the nervous system resulting in abdominal pain, vomiting, acute neuropathy, seizures, and mental disorders. The physiopathogeny results from the toxic effects of porphyrin precursors, and it can be triggered by drugs used routinely in medical practice, severe carbohydrate restriction, and metabolic stress. The objective of this report was to present the case of a late onset porphyria evolving to chronic pain.
\end{abstract}

Case report: This is a 27 years old female who was admitted 5 months prior to her clinic appointment with severe abdominal pain without diagnosis. An exploratory laparotomy was indicated, which failed to demonstrate a cause for her pain. The patient was exposed to surgical trauma and drugs that can trigger porphyria, such as ketoprophen, metoclopramide, and antibiotics, and she evolved with significant hyponatremia, increased liver enzymes, seizures, and loss of movements that led to be admitted to the Intensive Care Unit. After the diagnosis of porphyria was made, the patient remained with pain in the lower limbs, being referred to the Pain Department of Santa Casa de Misericórdia de São Paulo. Treatment with amitriptyline, gabapentin, opioid, and simple analgesics was instituted; however, the patient continued to present recurring episodes of porphyria and, feeling insecure with the conduction of the case, she stopped the treatment.

Conclusions: Porphyria is one of the rare groups of enzymatic disorders that remain unknown by the great majority of health professionals. Upon recognizing this lack of knowledge about the disease, the level of stress and insecurity of the patient increases hindering adhesion to and continuity of the treatment.

Keywords: DISEASES, Hematologic: porphyria; PAIN: neuropathic.

\section{INTRODUCTION}

Porphyrias are a group of inherited or acquired disorders involving heme synthesis. The term porphyria derives from the Greek, meaning purple. This name is attributed to a German medical student, Schultz, in 1874, referring to the purplish discoloration of bodily fluids of patients during the episodes. It has an incidence of $5 / 100,000$ people in the general population while in the psychiatric population the incidence of acute intermittent porphyria is up to $1 / 500$ patients, and untreated porphyria can be an important cause of psychiatric

Received from the Department of Pain and Palliative Care of Santa Casa de Misericórdia de São Paulo (SCSP), SP, Brazil.

1. Anestheiologist in Pain Treatment Post-Graduation at CET/SBA of SCSP 2. PhD in Medicine from UNIFESP, Coresponsible for the CET/SBA of SCSP; Coordinator of the Pain Department of SCSP

3. Assisting Physician of the Anesthesiology and Pain Department of SCSP

Submitted on May 4, 2010.

Approved on June 28, 2010.

Correspondence to:

Dr. Alysson $B$ O Santos

Av Chibarás, 44, AP 1301

Planalto Paulista

04076-000 - São Paulo, SP

E-mail: alyssonbruno@hotmail.com disorders ${ }^{1}$. Porphyria has two types of presentation, acute and cutaneous. Acute manifestations affect especially the central nervous system, resulting in abdominal pain, vomiting, acute neuropathy, seizures, and mental alterations including hallucinations, depression, paranoia, and anxiety. In case of involvement of the autonomous nervous system, patients can develop constipation, increase or decrease in blood pressure, tachycardia, and other cardiac arrhythmias. In severe cases, electrolyte imbalances with hyponatremia, paralysis of the medulla with respiratory arrest, and psychiatric disorders resulting in suicide, may develop. Its physiopathogeny is probably linked to the toxic effects of porphyrin precursors, $\delta$-aminolevulinic acid (ALA) and porphobilinogen (PBG), and it can be triggered by drugs (such as barbiturates, alcohol, carbamazepine, carisoprodol, clonazepam, diclofenac, metoclopramide, phenytoin and valproic acid, sulfa drugs, oral contraceptives, sedatives, and antibiotics), severe carbohydrate restriction, or metabolic stress induced by infections or surgical interventions. Cutaneous porphyrias affect primarily the skin leading to photosensitivity, bullae, necrosis of the skin and gingiva, pruritus, edema, and an increase of hairs in areas such as the forehead. The present report describes the case of a patient with neuropathic pain secondary to porphyria and the difficulties of the diagnosis and management of the patient with this painful presentation are discussed. 


\section{CASE REPORT}

This is a 27 years old female who was referred to the pain outpatient clinic of Santa Casa de Misericórdia de São Paulo by her endocrinologist with complaints of leg pain. The patient reported pain in the lower limbs for approximately 12 years, but after her hospitalization 5 months ago the pain worsened. Initially, it was believed that obesity was responsible for her pain. The patient was treated with sibutramine for 20 days and diet with restriction of carbohydrates, and she developed severe abdominal pain which led to an urgent laparotomy, which did not show any changes. In the second postoperative day, the patient developed seizures. She was transferred to the intensive care unit (ICU) where the presence of elevated liver enzymes and persistent hyponatremia was observed (115 mEq. $\left.\mathrm{L}^{-1}\right)$ even after sodium replacement. Upon discharge from the ICU, the patient did not show movements of the upper and lower limbs and she had severe pain throughout her body that did not respond to morphine. In the regular ward, she maintained the electrolyte imbalance and loss of movements, and nutritional and psychiatric follow-up was instituted. Movement of her limbs returned after resolution of the electrolyte imbalance. Two urinary analyses were undertaken upon admission to the hospital; both were negative for porphyria. One day before being discharged from the hospital, a new urinalysis gave a positive result. After being discharged from the hospital, motor disturbances had disappeared, but she remained with paresthesia and reduction of the sensitivity in the abdominal region until the knees bilaterally. At the moment of the consultation, the patient complained of pain in the lower limbs, as well as feeling tired and a feeling of increased weight in her legs, which worsened with a reduction in temperature, without relationship with movements, and with bouts of worsening of pain in large joints characterized as increased weight (VAS: 7). She was being treated with tramadol 100 mg every 12 hours as needed. The patient reported that her father had the same symptoms, but the diagnosis of porphyria was never made and he died due to pneumonia. The physical exam of the patient failed to show sensorial or motor changes. Electroneuromyography of the lower limbs was requested, and tramadol $200 \mathrm{mg}^{- \text {day }^{-1}}$, paracetamol, and amitriptyline $12.5 \mathrm{mg}$ at bed time were prescribed. One month later, the patient returned to the clinic referring partial pain control (VAS: 6) when gabapentin $300 \mathrm{mg}$ at bedtime was added to the treatment schedule. However, the patient still had not had the electroneuromyography. In the following appointment, the patient seemed very mistrustful and she did not have confidence in the medical care, since she believed no one really knew how to treat porphyria. She reported another episode in the period between appointments and she discontinued her medications. Tramadol and simple analgesic were prescribed once more and the patient was oriented on how to take them. However, the patient did not attend the follow-up appointment.

\section{DISCUSSION}

This patient had a typical history of acute porphyria. After a period of carbohydrate restriction in her diet, she developed an acute episode triggered by hypoglycemia that was wrongfully mistaken as acute abdomen and she underwent a laparotomy. The surgical stress and drugs contraindicated for those patients (metoclopramide, ketoprophen, and antibiotics) were used leading to worsening of her symptoms, causing electrolyte imbalances and seizures. Besides neuropathic visceral pain the patient also developed tetraplegia, and the differential diagnosis with systemic lupus erythematosus and Guillain-Barré syndrome is usually necessary ${ }^{2-4}$. Porphyria-induced peripheral neuropathy is fundamentally motor. Asymmetric paresis, which starts in the proximal upper limbs but that can be focal and may involve cranial nerves can be seen. Muscle weakness may progress to respiratory and medullar paralysis and death, especially if the diagnosis is delayed. Even advanced paralysis is reversible with adequate treatment, but it requires several months of rehabilitation. Pain can be severe and almost always requires the use of opioids. Patients who experience frequent episodes may develop chronic neuropathic pain in the extremities, as well as chronic pain the digestive tract. In those cases, treatment with long-acting opioids can be indicated. Long-term complications include hypertension, renal dysfunction, chronic liver damage, and hepatocellular carcinoma ${ }^{5,6}$. Some patients develop chronic neuropathic pain, which increases the risk of depression and suicide ${ }^{7}$.

Resting the diagnosis on the urine levels of porphobilinogen (PBG) may be misleading, especially if the urine is collected between episodes, making it difficult the correct diagnosis and treatment of this disorder ${ }^{8}$. Treatment is based on a carbohydrate-rich diet. In the United States and Great Britain, hematin and heme arginate are the drugs of choice to treat acute porphyria, respectively. This disease is usually accompanied by depression and seizures. Most drugs used to treat seizures potentiate the condition, making its treatment a problem. Some benzodiazepines are safe and, when used along with anticonvulsants such as gabapentin offer the possibility of seizure control. Blood transfusion is occasionally used to suppress the production of heme by the individual. Since involvement of the nervous system caused by porphyria is due to basically the neurotoxic effects of porphyrin precursors, amitriptyline associated with gabapentin, opioid, and simple analgesics was prescribed and an electroneuromyography was requested to confirm the neuronal lesion ${ }^{9}$. The lack of confidence of the patient with received successive treatments, the lack of knowledge of professionals about its pathology, and the absence of guidance to the patient about factors that can trigger an episode led to the difficulty of her acceptance for the treatment proposed.

The diagnosis of porphyria described in the XIX Century continues to be delayed, which exposes patients to inadequate treatments, worsening even more their situation. This reality will last as long as physicians do not have the differential diagnosis of porphyria in mind when facing young patients with severe abdominal pain associated with neuropathies and/or electrolyte imbalances. 


\section{REFERÊNCIAS / REFERENCES}

01. Tishler PV, Woodward B, O' Connor J et al. - High prevalence of intermittent acute porphyria in a psychiatric patient population. Am J Psychiatry, 1985;142:1430-1436.

02. Wikberg A, Andersson C, Lithner F - Signs of neuropathy in the lower legs and feet of patients with acute intermittent porphyria. $J$ Intern Med, 2000;248:27-32.

03. Albers JW, Fink JK - Porphyric neuropathy. Muscle Nerve, 2004; 30:410-422.

04. Roelandts $\mathrm{R}-$ The diagnosis of photosensitivity. Arch Dermatol, 2000;136:1152-1157.

05. Ostrowski J, Kostrzewska E, Michalak T et al. - Abnormalities in liver function and morphology and impaired aminopyrine metabolism in hereditary hepatic porphyrias. Gastroenterology, 1983;85:1131-1137.

06. Linet MS, Gridley G, Nyre'n O et al. - Primary liver cancer, other malignancies, and mortality risks following porphyria: a cohort study in Denmark and Sweden. Am J Epidemiol, 1999;149:1010-1015.

07. Jeans JB, Savik K, Gross CR et al. - Mortality in patients with acute intermittent porphyria requiring hospitalization: a United States case series. Am J Med Genet, 1996;65:269-273.

08. Anderson KE, Bloomer JR, Bonkovsky HL et al. - Recommendations for the diagnosis and treatment of the acute porphyrias. Ann Intern Med, 2005;142:439-450.

09. Lin CSY, Krishnan AV, Lee MJ et al. - Nerve function and dysfunction in acute intermittent porphyria. Brain, 2008;131:2510-2519.

Resumen: Santos ABO, Gozzani JL, Groke DF - Dolor Neuropático en Paciente con Porfiria: Relato de Caso.
Justificativa y objetivos: Las porfirias son un grupo de disturbios heredados o adquiridos que involucran las enzimas participantes en el proceso de síntesis del grupo hemo. Las manifestaciones agudas afectan el sistema nervioso, trayendo como resultando el dolor abdominal, vómitos, neuropatía aguda, convulsiones y disturbios mentales. La fisiopatogenia es el resultado del efecto tóxico de los precursores de la porfirina, pudiendo ser desencadenada por fármacos usados como rutina en la práctica médica, la restricción intensa de carbohidratos y por el estrés metabólico. El objetivo de este trabajo fue presentar un caso de porfiria de diagnóstico tardío, que evolucionó para dolor crónico.

Relato del caso: Paciente del sexo femenino, 27 años, ingresada hace 5 meses, con dolor abdominal intenso sin diagnóstico clínico. Fue indicada la laparotomía exploradora, que no mostró la causa para el cuadro. La paciente, expuesta al trauma quirúrgico y a los medicamentos que desencadenan crisis de porfiria, como el ceprofeno, la metoclopramina y los antibióticos, evolucionó con importante hiponatremia, elevación de enzimas hepáticas, convulsión y pérdida de los movimientos, y tuvo que ser ingresada en una Unidad de Cuidados Intensivos. Después del diagnóstico de porfiria, continuó con el dolor en los miembros inferiores y tuvo que ser derivada al Servicio de Dolor de la Santa Casa de Misericordia de São Paulo para tratamiento. Empezó el tratamiento con amitriptilina, gabapentina, opioide y analgésicos sencillos, pero continuó presentando crisis recurrentes de porfiria y como estaba insegura en cuanto a la conducción del caso, abandonó el acompañamiento.

Conclusiones: La porfiria es uno de los raros grupos de disturbios enzimáticos que permanecen sin conocerse por una gran parte de los profesionales de la salud. El paciente, al darse cuenta que no conoce la enfermedad, se estresa mucho más y se siente muy inseguro con respecto al tratamiento, dificultando su aplicación y continuidad. 